\title{
Effect of vanadyl doping on relative intensities of factor group split Raman bands in potassium oxalate monohydrate
}

\author{
NAVIN PANT ${ }^{1}$, A L VERMA ${ }^{1, *}$ and S D PANDEY ${ }^{2}$ \\ ${ }^{1}$ Department of Applied Physics, Amity Institute of Applied Sciences, Amity University, Sector-125, Noida 201313, India \\ ${ }^{2}$ P.P.N. College, P.G. Center, Kanpur University, Kanpur 208001, India \\ *Author for correspondence (alverma@amity.edu; alverma@yahoo.com)
}

MS received 16 November 2018; accepted 29 November 2018; published online 21 May 2019

\begin{abstract}
We report Raman spectral studies of pure potassium oxalate monohydrate, $\mathrm{K}_{2} \mathrm{C}_{2} \mathrm{O}_{4} \cdot \mathrm{H}_{2} \mathrm{O}$ (POM) and its doped varieties with 1 and 5\% vanadyl concentrations at room temperature. Apart from many other interesting changes in the Raman spectra on doping with $\mathrm{VO}^{2+}$, one of the most intriguing observations is the change in relative intensities of factor group split components of several Raman bands including some bands in the lattice mode region. We have explained the relative intensity changes of factor group split components in terms of locking of adjacent $\mathrm{C}_{2} \mathrm{O}_{4}-\mathrm{H}_{2} \mathrm{O}-\mathrm{C}_{2} \mathrm{O}_{4}-\mathrm{H}_{2} \mathrm{O}$ chains due to vanadyl doping in the POM lattice. The reduction in the intensities of water bands on vanadyl doping also supports this view.
\end{abstract}

Keywords. Raman spectra; potassium oxalate monohydrate (POM); vanadyl doping; factor group split Raman bands.

\section{Introduction}

The study of doped ions in a crystalline host has been the subject of scientific interest for a long time. The question arises as to how the neighbouring structure in the lattice is perturbed by the introduction of external impurities. We have chosen potassium oxalate monohydrate (POM) to understand how the bonding pattern in POM is affected on doping with some external impurities. POM plays an important role in nature, is found in many plants and is used in various medical and technological applications [1]. We have therefore tried to understand the structural changes induced in the lattice of POM on introducing vanadyl ions as external impurities using a Raman spectroscopic technique which provides direct evidence of structural changes at the microscopic level including lattice modes.

Moreover, we are interested in studying the structural changes using an electron spin resonance technique and also where paramagnetic vanadyl ions act as useful probes for electron paramagnetic resonance (EPR) investigations [2]. Many optical absorption and EPR studies are reported for vanadyl ions doped in a number of host lattices [3-7] and changes in energy levels/parameters are observed from one host to another.

Though X-ray and neutron diffraction studies are important established tools in crystal structure determination [8-10], when one wants to explore localized defects in crystals, an $\mathrm{X}$-ray technique does not seem much helpful. Vibrational and EPR studies are sometimes of immense help in this direction. The EPR technique [3-7] is quite characteristic of an immediate environment of the cation site and very small changes in the environment of doped ions could be identified. For such investigations, the vanadyl ion is a powerful probe. This is a linear molecular entity $(\mathrm{V}=\mathrm{O})$ and can substitute at lattice cationic locations or may occupy interstitial positions.

Raman spectroscopic techniques provide direct evidence of structural changes at the microscopic level including lattice modes. In this paper, we are presenting the results of our Raman study for undoped POM and its 1 and 5\% vanadyl doped varieties. It is interesting to find that the doped vanadyl ions do attenuate the intensities of some of the Raman bands and splitting of some bands is also observed.

The Raman studies of pure POM (both in powder and single crystal forms) have been reported from 80 to $3800 \mathrm{~cm}^{-1}$ by Eriksson and Nielson [11]. They have also assigned the observed bands in different spectral regions, though their spectral resolution was not adequate to resolve the bands due to $\mathrm{O}-\mathrm{H}$ stretching modes. Fukushima [12] has conducted infrared (IR) studies on pure POM. If POM is doped with vanadyl ions, the $\mathrm{V}=\mathrm{O}$ groups are reported to bind oxalate groups in the adjacent $\mathrm{H}_{2} \mathrm{O}-\mathrm{C}_{2} \mathrm{O}_{4}-\mathrm{H}_{2} \mathrm{O}$ chains, replace two potassium ions and occupy interstitial sites in the lattice, forming the $\mathrm{VO}\left(\mathrm{C}_{2} \mathrm{O}_{4}\right)_{2} \cdot \mathrm{H}_{2} \mathrm{O}$ complex [7]. Such a doping would influence the bonding arrangement and may affect the lattice and other vibrational and even rotational/librational motions of different groups in POM. The intensities of different factor group split components may not be affected equally with the above suggested bonding of the $\mathrm{V}=\mathrm{O}$ group. During our Raman investigations of vanadyl doped POM, we have observed very surprising and remarkable changes in the relative intensities of many factor group split components of Raman bands. We therefore undertook 
systematic Raman studies on POM doped with different concentrations of vanadyl ions and have attempted to explain the origin of such changes in this work.

\section{Crystal structure}

The crystal structure of $\mathrm{K}_{2} \mathrm{C}_{2} \mathrm{O}_{4} \cdot \mathrm{H}_{2} \mathrm{O}$ has been investigated by Hodgson and Ibers [13] from X-ray diffraction and by Chidambaram et al [10] using neutron diffraction techniques. $\mathrm{K}_{2} \mathrm{C}_{2} \mathrm{O}_{4} \cdot \mathrm{H}_{2} \mathrm{O}$ crystallizes as per the $C 2 / c\left(C^{6}{ }_{2 h}\right)$ space group in the monoclinic centrosymmetric lattice and the molecular symmetry of the oxalate group is $D_{2 h}$. It occupies the $\mathrm{C}_{\mathrm{i}}$ site in the unit cell while the factor group is $C^{6}{ }_{2 h}$. On the other hand, the water molecule has the $C_{2 v}$ molecular point group and occupies the $\mathrm{C}_{2}$ site in the solid.

The monoclinic crystals of POM consist of chains of oxalate ions with a water molecule present in each chain between the two neighbouring oxalate groups. The water molecule forms a hydrogen bond with the oxygens of the oxalate group. Two such neighbouring chains are held by $\mathrm{K}^{+}$ ions between them placed in general positions at the $\mathrm{C}_{1}$ site. The determined crystal parameters $[9,10]$ are: $a=9.223 \AA$, $b=6.197 \AA, c=10.690 \AA$ and $\beta=110.70^{\circ}$. The unit cell of the crystal has four formula units and each primitive cell contains two formula units.

Group theoretical analysis of different modes in the Raman spectrum of POM has been given by Eriksson and Nielson [11] in terms of internal, rotational (called librational modes in solids) and translational lattice modes including the symmetry correlation diagram. However, we shall give here only pertinent details for the ease of readers. Briefly, one would expect 66 normal modes from 22 atoms in the primitive cell of POM consisting of two formula units. Out of these, there will be 33 Raman active modes distributed as 12 internal vibrational modes of $\mathrm{C}_{2} \mathrm{O}_{4}\left(6 \mathrm{~A}_{\mathrm{g}}+6 \mathrm{~B}_{\mathrm{g}}\right), 3$ internal vibrations of $\mathrm{H}_{2} \mathrm{O}$ $\left(2 \mathrm{~A}_{\mathrm{g}}+1 \mathrm{~B}_{\mathrm{g}}\right), 6$ rotational (librational) modes of $\mathrm{C}_{2} \mathrm{O}_{4}\left(3 \mathrm{~A}_{\mathrm{g}}+\right.$ $\left.3 \mathrm{~B}_{\mathrm{g}}\right), 3$ rotational/librational modes of $\mathrm{H}_{2} \mathrm{O}\left(1 \mathrm{~A}_{\mathrm{g}}+2 \mathrm{~B}_{\mathrm{g}}\right)$ and 9 translational modes $\left(4 \mathrm{~A}_{\mathrm{g}}+5 \mathrm{~B}_{\mathrm{g}}\right)$. In IR, one would expect 12 internal vibrational modes of $\mathrm{C}_{2} \mathrm{O}_{4}\left(6 \mathrm{~A}_{\mathrm{u}}+6 \mathrm{~B}_{\mathrm{u}}\right)$, 3 internal vibrational modes of $\mathrm{H}_{2} \mathrm{O}\left(2 \mathrm{~A}_{\mathrm{u}}+1 \mathrm{~B}_{\mathrm{u}}\right), 3$ rotational/librational modes of $\mathrm{H}_{2} \mathrm{O}\left(1 \mathrm{~A}_{\mathrm{u}}+2 \mathrm{~B}_{\mathrm{u}}\right), 12$ translational modes $\left(6 \mathrm{~A}_{\mathrm{u}}+6 \mathrm{~B}_{\mathrm{u}}\right)$ and 3 acoustic modes $\left(1 \mathrm{~A}_{\mathrm{u}}+2 \mathrm{~B}_{\mathrm{u}}\right)$. The symmetry correlation diagram for $\mathrm{K}_{2} \mathrm{C}_{2} \mathrm{O}_{4} \cdot \mathrm{H}_{2} \mathrm{O}$ solid is shown in table 1.

The $X Y Z$ coordinate system for the oxalate group is chosen such that the $X-Y$ plane coincides with the molecular plane and the $Y$-axis is along the $\mathrm{C}-\mathrm{C}$ direction. For water, the $Z$ direction is taken along the two-fold axis and the $X$-direction lies perpendicular to the molecular plane. Figure 1 shows the projection of the POM crystal structure on the (010) plane as given by Chidambaram et al [10] and Kripal et al [7] which also shows the orientation of the $\mathrm{V}=\mathrm{O}$ group.

Being centrosymmetric, the interactions among the molecular units in the unit cell are expected to give rise to splitting of each mode into $A_{g}, B_{g}, A_{u}$ and $B_{u}$ components which is called the factor group splitting. Only the $\mathrm{A}_{\mathrm{g}}$ and $\mathrm{B}_{\mathrm{g}}$ component modes would be active in Raman scattering. The classification of the factor-group split components as symmetric $\left(\mathrm{A}_{\mathrm{g}}\right)$ and antisymmetric nature $\left(\mathrm{B}_{\mathrm{g}}\right)$ is visualized with respect to the common plane of the oxalate ion and the position of $\mathrm{H}_{2} \mathrm{O}$. Table 1 shows the symmetry correlation diagram for the $\mathrm{K}_{2} \mathrm{C}_{2} \mathrm{O}_{4} \cdot \mathrm{H}_{2} \mathrm{O}$ solid.

\section{Materials and methods}

Crystals of pure POM and POM doped with vanadium sulphate were grown from saturated solution at room temperature by slow evaporation. The saturated solution was prepared by dissolving analar grade POM along with 1 and 5\% vanadium sulphate by weight in distilled water. After nearly 12-14 days, small crystals were obtained which were ground to a powder form for Raman studies. The Raman spectra of the samples in the powder form were recorded using a JY-Horiba Model R-550 Raman spectrometer with a focal length of $55 \mathrm{~cm}$ and an aperture of f/6.4. The spectrometer was fitted with a Peltier cooled CCD detector. The Raman spectrometer was fitted with a microscopic arrangement for focusing the laser light to a micron size spot. The $514.5 \mathrm{~nm}$ argon ion laser line with $\sim 3 \mathrm{mw}$ power at the sample was used as the excitation source. The data were accumulated for $3 \mathrm{~s}$ and averaged over 200 scans to improve the $\mathrm{S} / \mathrm{N}$ ratio.

\section{Experimental}

Figure $2 \mathrm{~A}$ and $\mathrm{B}$ shows the Raman spectrum of undoped POM and the corresponding spectrum of 5\% vanadyl doped POM samples in the spectral region of $50-2000 \mathrm{~cm}^{-1}$, respectively. In the Raman spectrum of undoped POM, the $1443 \mathrm{~cm}^{-1}$ Raman band associated with the $\mathrm{C}=\mathrm{O}$ stretching mode is the strongest followed by the group of external vibrations and a clear doublet at 874 and $879 \mathrm{~cm}^{-1}$ associated with the C-C stretching mode. In 5\% vanadyl doped POM, Raman bands ascribable to external vibrations are quite strong. We present the Raman spectra of undoped POM along with 5\% vanadyl doped samples in figures 3, 4 and 5 on an expanded scale for clarity in the spectral ranges: 50-200, 400-700, 840-910, $1540-1640 \mathrm{~cm}^{-1}$ and $2900-3800 \mathrm{~cm}^{-1}$, respectively.

Before attempting to explain changes in the Raman spectra of POM doped with vanadyl ions, it is emphasized that two planar oxalate groups are bound through $\mathrm{H}_{2} \mathrm{O}$ molecules in the primitive unit cell of POM (figure 1). Therefore, symmetric and anti-symmetric nature of bands has to be visualized with respect to the water group joining the oxalate groups. Thus $\mathrm{C}=\mathrm{C}$ stretching will be considered symmetric or antisymmetric while keeping the position of linked $\mathrm{H}_{2} \mathrm{O}$ in mind. Similar implications have to be considered while examining the vibrations of $\mathrm{C}=\mathrm{O}$ and other groups. 
Table 1. Symmetry correlation diagram for $\mathrm{K}_{2} \mathrm{C}_{2} \mathrm{O}_{4} \cdot \mathrm{H}_{2} \mathrm{O}$ solid.

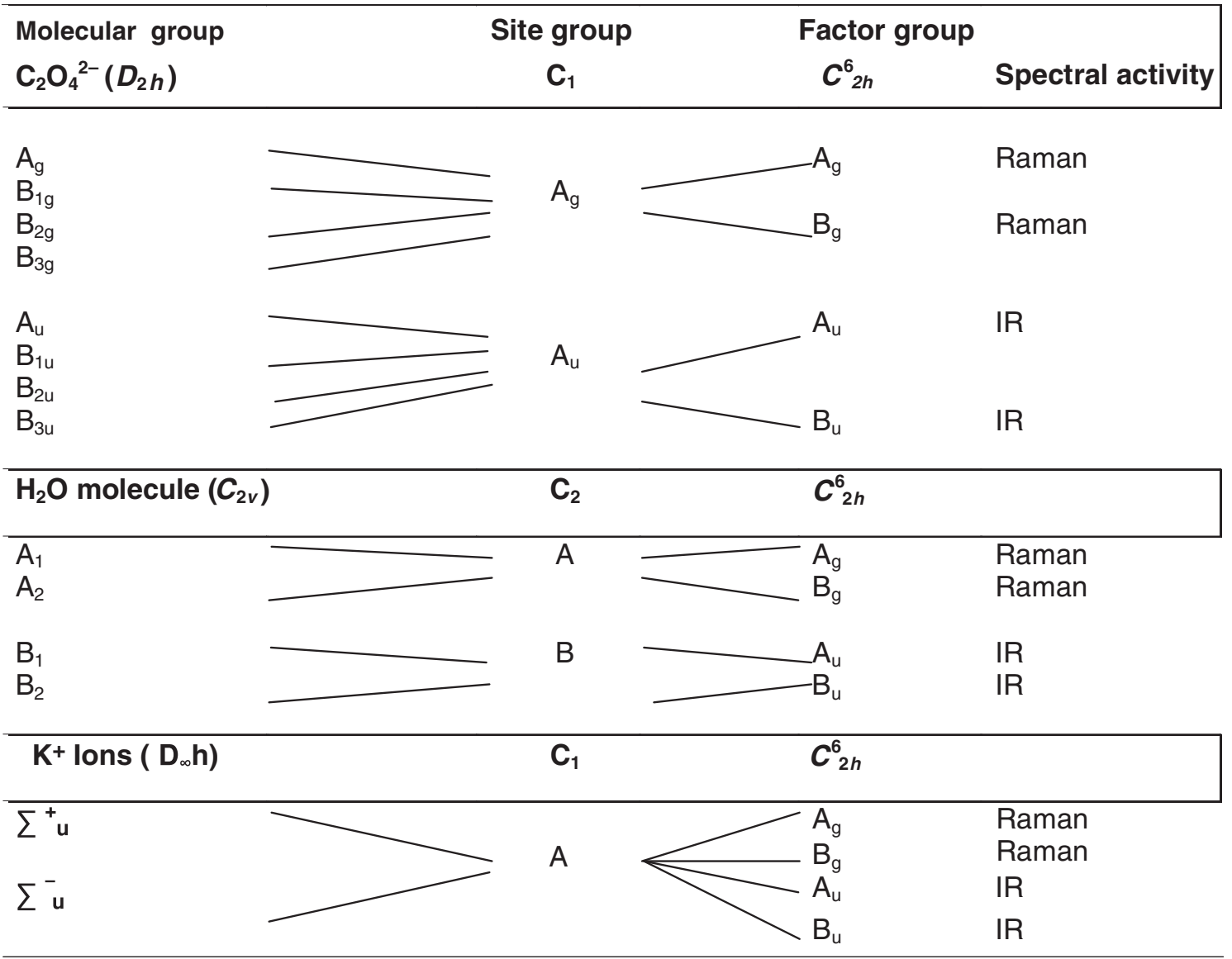

\section{Raman spectral data in different wavenumber regions}

In the following, we describe changes in the intensities of Raman bands in different spectral regions on vanadyl doping of POM. There are two traces. The top and bottom for each region corresponds to pure POM and $5 \% \mathrm{VO}^{2+}$ doped POM, respectively. The Raman intensity units are arbitrary.

\section{$5.1 \quad 50-200 \mathrm{~cm}^{-1}$ region}

In the pure POM, five prominent bands and two weak features with the symmetry type $A_{g} / B_{g}$ in the parenthesis are observed at different wavenumbers: $79 \mathrm{~cm}^{-1}\left(\mathrm{~A}_{\mathrm{g}} / \mathrm{B}_{\mathrm{g}}\right), 105 \mathrm{~cm}^{-1}\left(\mathrm{~B}_{\mathrm{g}}\right)$, $114 \mathrm{~cm}^{-1}\left(\mathrm{~A}_{\mathrm{g}} / \mathrm{B}_{\mathrm{g}}\right), 128 \mathrm{~cm}^{-1}\left(\mathrm{~A}_{\mathrm{g}}\right), 142 \mathrm{~cm}^{-1}\left(\mathrm{~A}_{\mathrm{g}} / \mathrm{B}_{\mathrm{g}}\right)$, $151 \mathrm{~cm}^{-1}\left(\mathrm{~A}_{\mathrm{g}} / \mathrm{B}_{\mathrm{g}}\right)$ and $162 \mathrm{~cm}^{-1}\left(\mathrm{~A}_{\mathrm{g}} / \mathrm{B}_{\mathrm{g}}\right)$ as shown in deconvoluted Raman bands in figure 3 . The intensities of all the bands except for the $105 \mathrm{~cm}^{-1}$ band decreases on vanadyl doping. In the $\mathrm{VO}^{2+}$ doped samples, additional bands appear at 56 and $68 \mathrm{~cm}^{-1}$. The latter of these bands has also been reported by Fukushima [10] in their IR spectrum. The relative intensity of the $114 \mathrm{~cm}^{-1}$ band decreases sharply compared to the intensity of the $105 \mathrm{~cm}^{-1}$ band in the Raman spectrum of $\mathrm{VO}^{2+}$ doped samples.

\section{$5.2400-650 \mathrm{~cm}^{-1}$ region}

As shown in figure $4 \mathrm{~A}$, the 472 and $555 \mathrm{~cm}^{-1}$ bands in pure POM reduce in intensity on vanadyl doping. Again, the $625 \mathrm{~cm}^{-1}$ band due to $\mathrm{H}_{2} \mathrm{O}$ rocking/librational motion reduce in intensity and is virtually lost in the noise due to reduction of water at regular sites in the 5\% vanadyl doped POM.

\section{$5.3840-920 \mathrm{~cm}^{-1}$ region}

Figure 4B shows the Raman spectrum in the region from 840 to $910 \mathrm{~cm}^{-1}$. The factor group split components of the Raman bands due to the $\mathrm{C}-\mathrm{C}$ stretching mode at $875 \mathrm{~cm}^{-1}\left(\mathrm{~A}_{\mathrm{g}}\right)$ and $879 \mathrm{~cm}^{-1}\left(\mathrm{~B}_{\mathrm{g}}\right)$ respectively in pure POM are observed. The intensity of the $\mathrm{B}_{\mathrm{g}}$ component at $879 \mathrm{~cm}^{-1}$ decreases sharply relative to the $\mathrm{A}_{\mathrm{g}}$ component at $875 \mathrm{~cm}^{-1}$ on vanadyl doping.

\section{$5.4 \quad 1540-1640 \mathrm{~cm}^{-1}$ region}

A doublet at $1598\left(\mathrm{~B}_{\mathrm{g}}\right)$ and $1604\left(\mathrm{~A}_{\mathrm{g}}\right) \mathrm{cm}^{-1}$ corresponding to the $\mathrm{C}=\mathrm{O}$ antisymmetric stretching mode in pure $\mathrm{POM}$ is observed in the Raman spectrum. On doping the POM with 


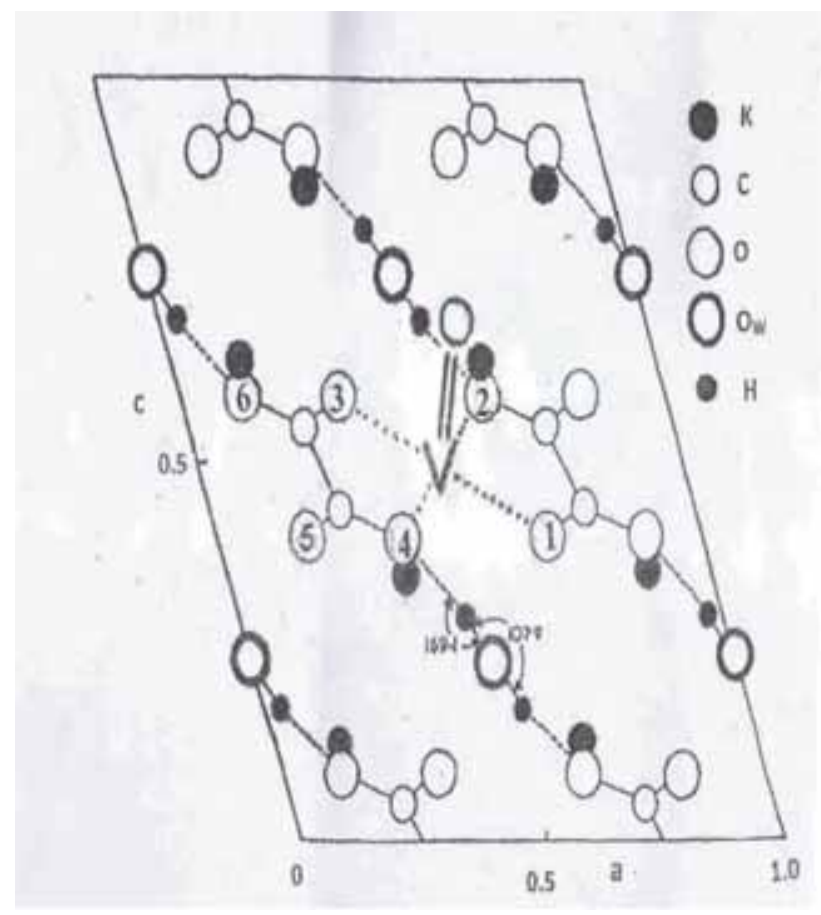

Figure 1. Projection of the crystal structure of POM on the (010) plane (based on references $[7,10]$ ) showing the position of the $\mathrm{V}=\mathrm{O}$ group.
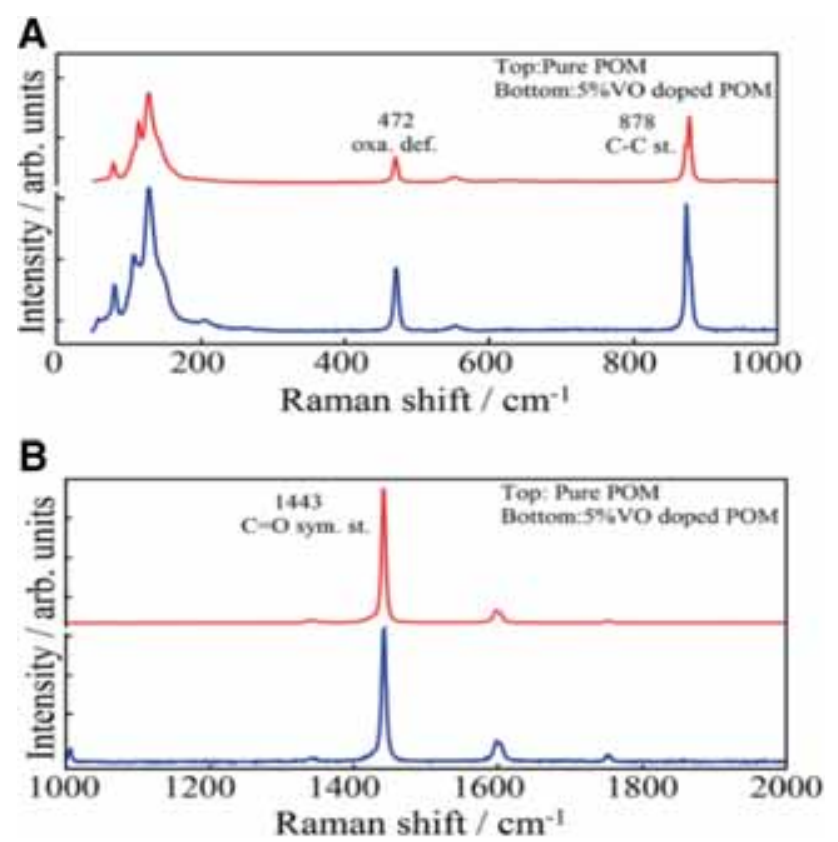

Figure 2. (A, B) Raman spectra of polycrystalline undoped POM and POM doped with $5 \%$ vanadyl ions at room temperature in the spectral region of $50-2000 \mathrm{~cm}^{-1}$.

vanadyl ions, the relative intensity of the $\mathrm{B}_{\mathrm{g}}$ component at $1598 \mathrm{~cm}^{-1}$ reduces greatly compared to the $\mathrm{A}_{\mathrm{g}}$ component at $1604 \mathrm{~cm}^{-1}$ as is evident from figure 5A.
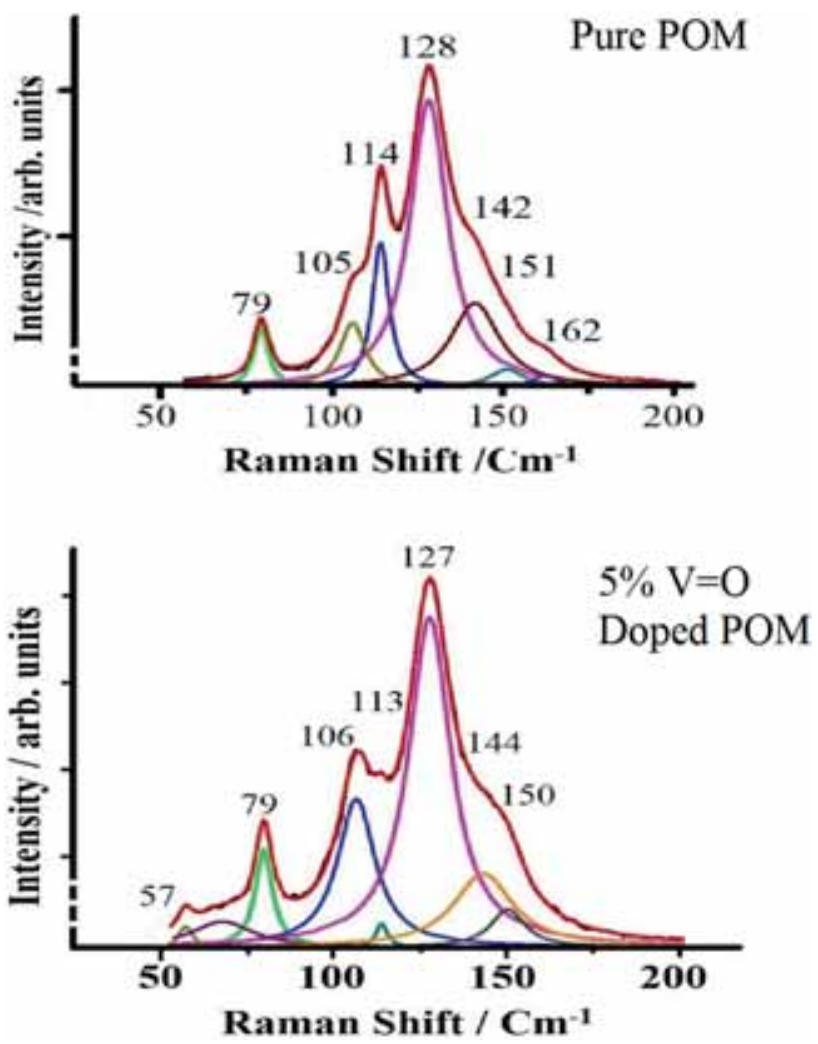

Figure 3. Relative intensities of different Raman bands of undoped and 5\% VO doped POM at room temperature in the spectral region of $50-200 \mathrm{~cm}^{-1}$. This portion of the spectrum has been deconvoluted using Lorentzian line shape function which makes relative intensities and the band position of different components much clear.

\section{$5.5 \quad 2800-3800 \mathrm{~cm}^{-1}$ region}

The Raman spectrum in this wavenumber region is shown in figure 5B. The relative intensities of water bands decrease due to reduction in the number of $\mathrm{H}_{2} \mathrm{O}$ groups at regular crystal sites due to vanadyl doping in POM. Moreover, the Raman bands arising from stretching modes of $\mathrm{OH}^{-}$ions created by dissociation of $\mathrm{H}_{2} \mathrm{O}$ may be buried in the broad bands in this region and the relative intensity changes and/or shift in band positions are neither significant nor follow any systematic pattern. However, we have observed clearly resolved Raman bands due to symmetric and antisymmetric $\mathrm{O}-\mathrm{H}$ stretching modes at 3262 and $3400 \mathrm{~cm}^{-1}$ respectively while Eriksson and Nielsen [11] observed only one band at $\sim 3250 \mathrm{~cm}^{-1}$ in this spectral region.

\section{Discussion}

From Raman studies on single crystal of POM, Eriksson and Nielsen [11] have associated the split components of some Raman bands due to factor group splitting. The contribution of the site group splitting in the splitting of the bands arising 


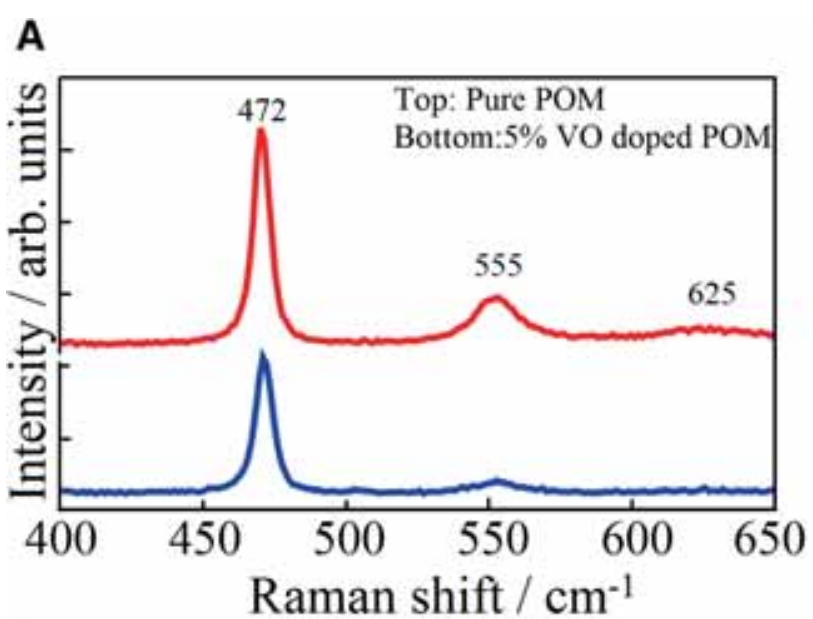

B

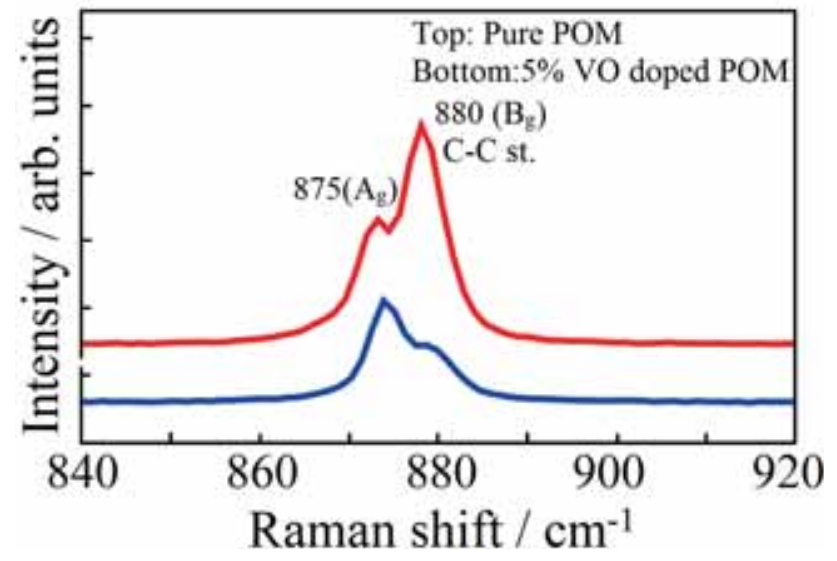

Figure 4. (A) Relative intensities of Raman bands of undoped and $5 \%$ VO doped POM at room temperature in the spectral region of $400-650 \mathrm{~cm}^{-1}$. (B) Relative intensities of Raman bands of undoped and $5 \%$ VO doped POM at room temperature in the spectral range of $840-920 \mathrm{~cm}^{-1}$.

from occupancy of $\mathrm{VO}^{2+}$ ions on different sites can be ruled out as, in general, the site group split components in Raman bands are more widely separated than observed in our studies.

If POM is doped with a vanadyl ion, the $\mathrm{V}=\mathrm{O}$ group would bind oxalate groups in the adjacent $\mathrm{C}_{2} \mathrm{O}_{4}-\mathrm{H}_{2} \mathrm{O}-\mathrm{C}_{2} \mathrm{O}_{4}-\mathrm{H}_{2} \mathrm{O}$ chains. Thus $\mathrm{VO}^{2+}$ would link with the oxygens $\mathrm{O}(1), \mathrm{O}(2)$, $\mathrm{O}(3)$ and $\mathrm{O}(4)$ to form a complex $\mathrm{VO}\left(\mathrm{C}_{2} \mathrm{O}_{4}\right)_{2} \cdot \mathrm{H}_{2} \mathrm{O}$. In this complex, $\mathrm{V}=\mathrm{O}$ would obviously point perpendicular to the plane formed by $\mathrm{O}(1), \mathrm{O}(2), \mathrm{O}(3)$ and $\mathrm{O}(4)$ atoms. Such a complex formation was established by Kripal et al [7] through their EPR studies in vanadyl doped POM. The orientation of complexed $\mathrm{V}=\mathrm{O}$ in $\mathrm{POM}$ and relevant ' $g$ ' and ' $A$ ' parameters were also obtained by Kirpal et al [7].

\subsection{Intensity of $B_{\mathrm{g}}$ type modes}

The particular planar and tightly bound atoms in oxalate ions and the orientation of the $\mathrm{V}=\mathrm{O}$ complex with respect to the surrounding oxygens provide a clue that during the $\mathrm{B}_{\mathrm{g}}$ type
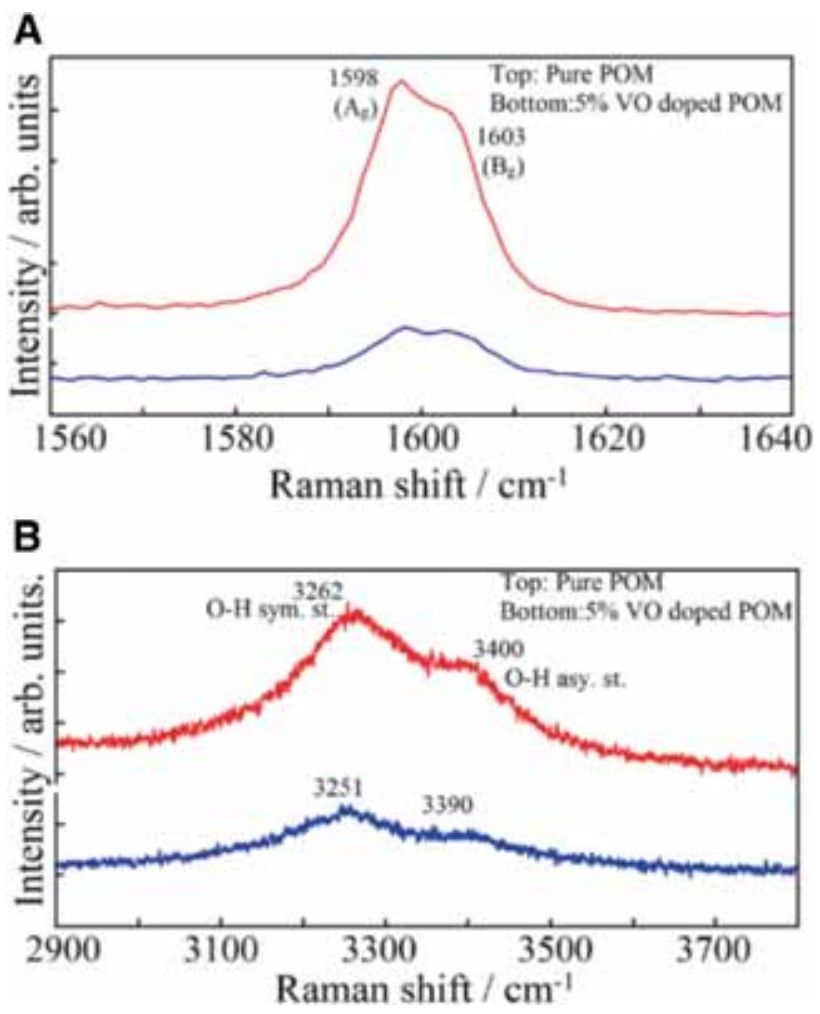

Figure 5. (A) Relative intensities of Raman bands of undoped and 5\% VO doped POM at room temperature in the spectral range of $1540-1640 \mathrm{~cm}^{-1}$. (B) Relative intensities of Raman bands of undoped and 5\% VO doped POM at room temperature in the spectral range of $2900-3800 \mathrm{~cm}^{-1}$.

modes, the atomic species move perpendicular to the oxalate plane and their movement would be restricted resulting in a decrease in the polarizability change and intensity of $\mathrm{B}_{\mathrm{g}}$ type modes. On the other hand, $\mathrm{A}_{\mathrm{g}}$ type modes involve the movement of atoms in the oxalate plane which would not be much affected due to vanadyl doping in POM. This is further clarified as per discussion below.

The orientations of the plane of the oxalate group containing oxygens $\mathrm{O}(3), \mathrm{O}(4), \mathrm{O}(5)$ and $\mathrm{O}(6)$ and the planes $\mathrm{O}(1)$, $\mathrm{O}(2), \mathrm{O}(3)$ and $\mathrm{O}(4)$ of oxygens in the vanadyl complex can be seen in figure 1 .

When vanadyl ions are doped in POM as shown in figure 1, the oxygens $\mathrm{O}(3)$ and $\mathrm{O}(4)$ are locked to the adjacent $\mathrm{O}(1)$ and $\mathrm{O}(2)$ oxygens through the $\mathrm{V}^{4+}$ ion which forms strong covalent bonds with all the four oxygens $\mathrm{O}(1), \mathrm{O}(2), \mathrm{O}(3)$ and $\mathrm{O}(4)$.

From the position of oxygens surrounding $\mathrm{V}^{4+}$ and the position of carbon atoms, according to the crystal data [10], it can be estimated that the carbon-O(3) bond makes an angle of $81^{\circ}$ with the $\mathrm{O}(3)-\mathrm{V}$ bond and the carbon-O(4) bond makes an angle of $77^{\circ}$ with the $\mathrm{O}(4)-\mathrm{V}$ bond in the threedimensional image. With this image, it is easier to visualize that the out of plane movement of the atomic species during $\mathrm{B}_{\mathrm{g}}$ type vibrations would be greatly hampered due to tightly bound coupling of oxalate chains through vanadyl bonding. 
Table 2. Vibrational data for $\mathrm{K}_{2} \mathrm{C}_{2} \mathrm{O}_{4} \cdot \mathrm{H}_{2} \mathrm{O}$ and $\mathrm{VO}^{2+}$ doped $\mathrm{K}_{2} \mathrm{C}_{2} \mathrm{O}_{4} \cdot \mathrm{H}_{2} \mathrm{O}$ at room temperature.

\begin{tabular}{|c|c|c|c|c|c|c|c|}
\hline \multirow[b]{2}{*}{ Sl. no. } & \multirow[b]{2}{*}{$\begin{array}{l}\text { FTIR } \\
\text { (Fukushima) }\end{array}$} & \multirow[b]{2}{*}{$\begin{array}{l}\text { Raman } \\
\text { (Eriksson) }\end{array}$} & \multicolumn{3}{|c|}{ Present work } & \multirow[b]{2}{*}{ Mode symmetry } & \multirow[b]{2}{*}{$\begin{array}{l}\text { Mode description } \\
\quad \text { (approx.) }\end{array}$} \\
\hline & & & Pure POM & $\begin{array}{l}1 \% \mathrm{VO}^{2+} \\
\text { doped POM }\end{array}$ & $\begin{array}{l}5 \% \mathrm{VO}^{2+} \\
\text { doped POM }\end{array}$ & & \\
\hline 1 & 56 & - & - & $56 \mathrm{vW}$ & $57 \mathrm{vw}$ & & \\
\hline 2 & & $82 \mathrm{w}$ & $79 w$ & $79 w$ & $81 \mathrm{w}$ & $A_{g}, B_{g}$ & \\
\hline 3 & 92 & - & - & - & - & - & \\
\hline 4 & - & $103 \mathrm{vw}$ & $105 \mathrm{sh}$ & $106 \mathrm{~m}$ & $107 \mathrm{~m}$ & $\mathrm{~B}_{\mathrm{g}}$ & \\
\hline 5 & 115 & $112 \mathrm{~m}$ & $113 \mathrm{~s}$ & $113 \mathrm{~m}$ & $111 \mathrm{sh}$ & $A_{g}, B_{g}$ & \\
\hline 6 & - & $118 \mathrm{~m}$ & - & - & - & $\mathrm{A}_{\mathrm{g}}$ & \\
\hline 7 & 129 & $130 \mathrm{~s}$ & $129 \mathrm{vs}$ & $128 \mathrm{~s}$ & $128 \mathrm{~s}$ & $\mathrm{~A}_{\mathrm{g}}$ & Lattice modes \\
\hline 8 & - & $141 \mathrm{sh}$ & $142 \mathrm{sh}$ & $141 \mathrm{sh}$ & $143 \mathrm{sh}$ & $\mathrm{A}_{\mathrm{g}}, \mathrm{B}_{\mathrm{g}}$ & \\
\hline \multirow[t]{2}{*}{9} & & $150 \mathrm{sh}$ & - & - & - & $\mathrm{A}_{\mathrm{g}}, \mathrm{B}_{\mathrm{g}}$ & \\
\hline & 160 & $162 \mathrm{sh}$ & $163 \mathrm{sh}$ & $163 \mathrm{sh}$ & $163 \mathrm{sh}$ & $A_{g}, B_{g}$ & \\
\hline 10 & 190 & - & - & - & - & - & \\
\hline 11 & 210 & - & - & - & - & - & \\
\hline 12 & 351 & - & - & - & - & - & $\gamma$ \\
\hline 13 & - & $473 \mathrm{~s}$ & 472 vs & $470 \mathrm{vs}$ & $470 \mathrm{~m}$ & $\mathrm{~A}_{\mathrm{g}}, \mathrm{B}_{\mathrm{g}}$ & Oxalate def. mode, sym. \\
\hline & & & & & & & $\mathrm{O}-\mathrm{C}-\mathrm{O}$ bending \\
\hline 14 & 524 & - & - & - & - & - & \\
\hline 15 & - & $556 \mathrm{~m}$ & $555 \mathrm{wm}$ & $555 \mathrm{w}$ & $555 \mathrm{vw}$ & $\mathrm{A}_{\mathrm{g}}, \mathrm{B}_{\mathrm{g}}$ & $\begin{array}{l}\text { Oxalate in-plane def. } \\
\text { mode mixed with } \mathrm{H}_{2} \mathrm{O} \\
\text { lattice mode }\end{array}$ \\
\hline 16 & 614 & - & - & - & - & - & \\
\hline 17 & - & $627 \mathrm{vw}$ & $625 \mathrm{vw}$ & $\begin{array}{l}620 \text { vvw and } \\
\text { diffused }\end{array}$ & - & $\mathrm{B}_{\mathrm{g}}$ & $\mathrm{H}_{2} \mathrm{O}$ rocking/libration \\
\hline 18 & 718 & $720 \mathrm{vw}$ & - & - & - & $\mathrm{B}_{\mathrm{g}}$ & $\mathrm{H}_{2} \mathrm{O}$ wagging/libration \\
\hline \multirow[t]{2}{*}{19} & & 876 vs & $875 \mathrm{~m}$ & $874 \mathrm{~s}$ & $874 \mathrm{~s}\}$ & $\mathrm{A}_{\mathrm{g}}$ & \multirow[b]{2}{*}{$\nu_{\mathrm{c}-\mathrm{c}}, \mathrm{C}-\mathrm{C}$ sym. str. } \\
\hline & - & 881 vs & $879 \mathrm{~s}$ & $879 \mathrm{~s}$ & $879 \mathrm{w}$ & $\mathrm{B}_{\mathrm{g}}$ & \\
\hline \multirow[t]{2}{*}{20} & & & & 980 & - & & \multirow[b]{2}{*}{$\nu_{\mathrm{v}=0}, \mathrm{~V}=\mathrm{O}$ sym. str. } \\
\hline & - & - & - & $1002 \mathrm{vvw}$ & $1003 \mathrm{vvw}$ & - & \\
\hline 21 & - & $\sim 1095 \mathrm{vw}$ & - & - & - & - & $2 \mathrm{x} 556 \mathrm{~cm}^{-1}$, overtone \\
\hline 22 & & $1342 \mathrm{w}$ & 1343 vw & 1338 vw & $1334 \mathrm{vvw}$ & $\mathrm{A}_{\mathrm{g}}, \mathrm{B}_{\mathrm{g}}$ & $\begin{array}{l}\nu_{\mathrm{c}-\mathrm{c}} \text { sym. Str. }+473 \mathrm{~cm}^{-1}, \\
\text { combination }\end{array}$ \\
\hline 23 & - & $1444 \mathrm{vs}$ & $1443 \mathrm{vs}$ & 1443 vs & $1443 \mathrm{vs}$ & $\mathrm{A}_{\mathrm{g}}, \mathrm{B}_{\mathrm{g}}$ & $\nu_{\mathrm{c}-\mathrm{o}}$, sym. $\mathrm{C}-\mathrm{O}$ str. \\
\hline \multirow[t]{2}{*}{24} & & $1600 \mathrm{~s}$ & $1598 \mathrm{~m}$ & $1600 \mathrm{~m}$ & $1600 \mathrm{w}\}$ & $\mathrm{A}_{\mathrm{g}}$ & \multirow[b]{2}{*}{$v_{\mathrm{c}-\mathrm{o}}$, asy. $\mathrm{C}-\mathrm{O}$ str. } \\
\hline & - & $1606 \mathrm{~m}$ & $1604 \mathrm{sh}$ & $1605 \mathrm{sh}$ & $1606 \mathrm{w} J$ & $\mathrm{~B}_{\mathrm{g}}$ & \\
\hline 25 & - & $1754 \mathrm{w}$ & - & - & - & $\mathrm{A}_{\mathrm{g}}$ & $2 \mathrm{x} \boldsymbol{v}_{\mathrm{c}-\mathrm{c},}, \quad$ str. overtone \\
\hline 26 & - & $\sim 3250 \mathrm{vw}, \mathrm{b}$ & $3262 \mathrm{~m}$ & $3260 \mathrm{vw}$ & $3251 \mathrm{vw}$ & $\mathrm{Ag}, \mathrm{Bg}$ & $v_{\mathrm{O}-\mathrm{H},}$ sym. O-H str. \\
\hline 27 & - & - & $3400 \mathrm{~b}, \mathrm{sh}$ & $3383 \mathrm{w}, \mathrm{sh}$ & $3390 \mathrm{vw}$ & $\mathrm{A}_{\mathrm{g}}, \mathrm{B}_{\mathrm{g}}$ & $v_{\mathrm{OH}}$, asy. $\mathrm{O}-\mathrm{H}$ str. \\
\hline
\end{tabular}

Abbreviations: s, strong; m, medium; w, weak; b, broad; sh, shoulder; v, very; vvw, very very weak; str, stretching mode; sym, symmetric; asy, asymmetric. 
On the other hand, $\mathrm{A}_{\mathrm{g}}$ type modes involving motion of atomic species in the oxalate plane would not be much affected due to vanadyl doping in POM.

The reduction in the intensities of various Raman bands can thus be satisfactorily understood as per discussion given above. Further, as any oxalate ion is linked to a neighbouring oxalate through a water group under inversion symmetry, any decrease in intensities of the $B_{g}$ mode in one oxalate group will be reflected in the nearest-neighbouring oxalate locked chains also. In other words, doping by single $\mathrm{V}=\mathrm{O}$ group would thus affect the intensities of $B_{g}$ modes in six oxalate groups.

\subsection{Intensities of $\mathrm{H}_{2} \mathrm{O}$ vibrational modes}

We observed weak-medium and very weak intensity Raman bands associated with water molecules at $556 \mathrm{~cm}^{-1}\left(\mathrm{~A}_{\mathrm{g}}, \mathrm{B}_{\mathrm{g}}\right)$, $627 \mathrm{~cm}^{-1}\left(B_{\mathrm{g}}\right)$ and $720 \mathrm{~cm}^{-1}\left(\mathrm{~B}_{\mathrm{g}}\right)$, respectively. When $\mathrm{V}=\mathrm{O}$ is doped in POM, water groups need to leave regular sites and some of these may even break into $\mathrm{H}^{+}$and $\mathrm{OH}^{-}$ions. The latter ions may coordinate with the displaced $\mathrm{K}^{+}$ions. Thus even allowed $\mathrm{B}_{\mathrm{g}}$ type vibrations associated with water molecules would decrease in intensity on vanadyl doping, as observed.

The locking of oxalate group chains may alter the local symmetry activating the otherwise some forbidden IR modes in Raman scattering. Further, Fukushima [14] has made lattice dynamical calculations for finding the vibrational modes for POM based on force constants between $\mathrm{K}^{+}$and oxalate groups. The data obtained therein have been used to explain the observation of IR bands at 56 and $92 \mathrm{~cm}^{-1}$ and predict a band at $\sim 50 \mathrm{~cm}^{-1}$. There is a possibility of some combination bands overlapping with the 105 and $113 \mathrm{~cm}^{-1}$ Raman bands. The apparent increase in the intensity of the $105 \mathrm{~cm}^{-1}$ band relative to the $113 \mathrm{~cm}^{-1}$ band on vanadyl doping may be expected with an increase in disorder in the lattice on vanadyl doping.

The vibrational data for pure POM and vanadyl doped POM at room temperature for two vanadyl concentrations are shown in table 2. We have also included the Raman data by Eriksson and Nielsen [11] and IR data by Fukushima [14] along with mode description for easy comparison.

\section{Conclusions}

The observed changes in the relative intensities of factor group split components of some Raman bands in POM have been reasonably well explained. The relative intensity changes arise from locking of adjacent $\mathrm{C}_{2} \mathrm{O}_{4}-\mathrm{H}_{2} \mathrm{O}-\mathrm{C}_{2} \mathrm{O}_{4}-\mathrm{H}_{2} \mathrm{O}$ chains on vanadyl doping in the lattice of POM through the formation of a complex $\mathrm{VO}\left(\mathrm{C}_{2} \mathrm{O}_{4}\right)_{2} \cdot \mathrm{H}_{2} \mathrm{O}$. The role of vanadyl doping is further reflected in the appearance of additional very weak Raman features at 57 and $67 \mathrm{~cm}^{-1}$ in the $\mathrm{V}=\mathrm{O}$ doped samples. The appearance of the IR active mode at $56 \mathrm{~cm}^{-1}$ suggests that vanadyl linkage inside POM eliminates the inversion symmetry. This may also be responsible for the appearance of some additional weak features in the 5\% $\mathrm{V}=\mathrm{O}$ doped $\mathrm{POM}$ samples. The present conclusions thus corroborate EPR results of Kripal et al about such complexes in vanadyl doped POM. The intensity changes also support the decrease in water content at regular sites in the $\mathrm{VO}^{2+}$ doped POM.

\section{Acknowledgements}

The authors are thankful to Professor R K Singh of Banaras Hindu University, Varanasi, India for help in recording of Raman spectra.

\section{References}

[1] Dinnebier R E, Vensky S, Panthofer M and Jansen M 2003 Inorg. Chem. 421499

[2] Pant N, Verma A L, Pandey S D and Kirpal R 2018 Natl. Acad. Sci. Lett. 41 255, https://doi.org/10.1007/s40009-018-0644-Z

[3] Jain V K 1980 Phys. Stat. Sol.(b) 97337

[4] Pake G E 2012 Paramagnetic resonance-an introductory monograph (Whitefish, Montana, USA: Literary Licensing, LLC)

[5] Bandopadhayay A 1980 J. Mater. Sci. 16189

[6] Jain V K, Seth V P and Malhotra R 1984 J. Phys. Chem. Solids 45529

[7] Kripal R, Maurya M and Govind H 2007 Physica B 392281

[8] Tanner A 2012 X-ray and neutron dynamical diffraction (New York: Springer)

[9] Singh A K 2005 Advance X-ray Techniques in Research and Industry, IOS Pr. Inc. ISBN: 1586035371

[10] Chidambaram R, Sequeria A and Sikka S K 1964 J. Chem. Phys. 413616

[11] Eriksson A and Nielsen O F 1978 J. Mol. Struct. 48343

[12] Fukushima K 1970 Bull. Chem. Soc. Japan 4339

[13] Hodgson D J and Ibers J A 1969 Acta Crystalogr. B 25469

[14] Kunio Fukushima K 1970 Bull. Chem. Soc. Japan 431313 